\title{
The Social Sustainability of Public Debt in the Framework of Middle East and North African Countries: Egypt, Lebanon, Morocco, Tunisia, and Turkey
}

\author{
Wissem Ajili ${ }^{1}$ \& Hassan Ayoub ${ }^{2}$ \\ ${ }^{1}$ Higher School of Management, University of Carthage, Bizerte, Tunisia \\ ${ }^{2}$ Faculty of Economics and Business Administration, Lebanese University, Beirut, Lebanon \\ Correspondence: Wissem Ajili, Higher School of Management, University of Carthage, 7035 Bizerte, Tunisia. E- \\ mail: ajiliouissem@yahoo.fr
}

\author{
Received: April 5, $2020 \quad$ Accepted: June 17, $2020 \quad$ Online Published: July 30, 2020 \\ doi:10.5539/jsd.v13n4p251 URL: https://doi.org/10.5539/jsd.v13n4p251
}

\begin{abstract}
The paper's main objective is to analyze the social sustainability of the external public debt of some MENA countries, namely, Egypt, Lebanon, Morocco, Tunisia, and Turkey between 1990 and 2018. The study carries out a dual statistical and econometric analysis to determine the impact of external public debt on the population welfare. The first analysis aims to examine the evolution of the debt social sustainability indicators and the second uses the Auto Regressive Distributed Lag (ARDL) panel data estimation technique.

Statistical analysis reveals that the external public debt service weighs heavily on public spending in health, education, and public investment. While the econometric study establishes that the ratio of external public debt as a percentage of Gross Domestic Product (GDP) has a negative effect on the population's standards of living.

The study concludes that external public debt in MENA countries has been used to finance non-productive expenditures, which have no effect on the population's living conditions. It highlights the need to consider the views of both debtors and creditors to achieve a comprehensive and sustainable approach to public debt. The latter should integrate the social and environmental consequences of debt on the well-being and living conditions of the population.
\end{abstract}

Keywords: external public debt, social sustainability, sustainable development, MENA economies

\section{Introduction}

During the last decade, both developed and developing countries had experienced high levels of public debt. In 2018, countries such as the United States, Japan, Belgium, Greece, Italy, and Portugal recorded public debt rates above $100 \%$ of Gross Domestic Product (GDP). Paradoxically, Statistics in figure 1 show that on average developing countries had experienced lower levels of public debt. However, some of these economies may face a debt sustainability problem. However, some of these economies may face a debt sustainability problem. The level of public debt in percentage of GDP reached respectively $28 \%$ in Turkey, $65 \%$ in Morocco, $77 \%$ in Tunisia and $151 \%$ in Lebanon.

The analysis by the thresholds where sovereign debt is summarized in a ratio (that of the public debt to GDP) seems to be irrelevant and lacks legitimacy. Admittedly, it is a simple and operational tool that synthesizes the debt problem into a prudential ratio. However, its arbitrary character makes it less and less credible (Aglietta, 2011; Chavagneux, 2012; Humbert, 2016). 


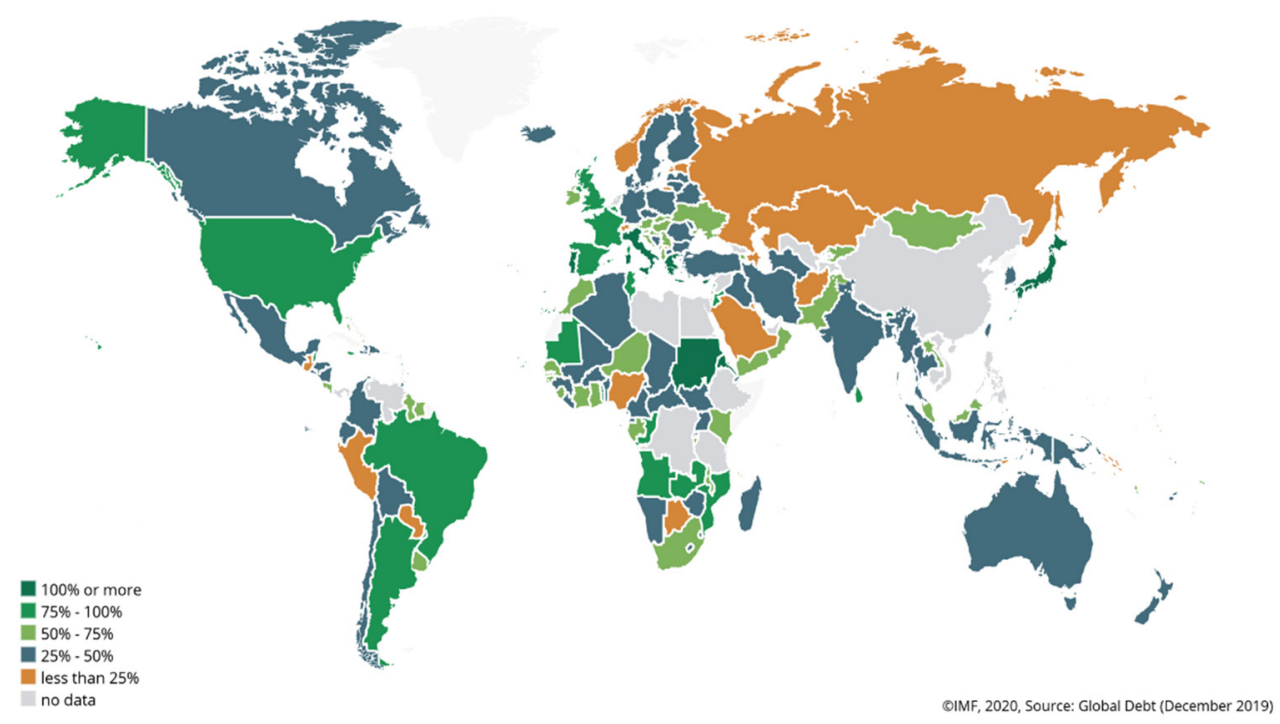

Figure 1. Central government debt (Percentage of GDP, 2018)

The international community's awareness of the limits of sustainability through debt thresholds has shifted the debate towards new approaches advocating social sustainability as the ultimate objective of public debt management policies. In recent years, attempts have been made to refocus the debate on the effects of foreign debt on the socio-economic rights of indebted countries. The issue of developing countries' indebtedness is being addressed from a new perspective that of the co-responsibility of creditor and debtor countries in debt sustainability. In this context, the United Nations has appointed an independent expert to examine the effects of foreign debt on the economic, social, and cultural rights of developing countries. In his initial report of 2009 (Note 1), the independent expert emphasized that "creditor and debtor countries have equal responsibility for preventing and resolving unsustainable debt". In the version transmitted to the United Nations General Assembly (Note 2), the independent expert maintains that "the principle of co-responsibility of debtors and creditors is at the heart of an equitable global financial system". Accordingly, and "in accordance with the principle of shared responsibility, it is important that lenders examine the extent to which they have contributed to the debt overhang of developing countries and recognize their responsibility in this regard."

Nonetheless, the implementation of the co-responsibility's concept meets several obstacles, mainly of a conceptual nature. Indeed, the key element of the notion of shared responsibility remains that of defining the concept of "illegitimate" debt according to unanimously accepted criteria. This task is far from being achieved currently.

In 2009, the United Nations Conference on Trade and Development (UNCTAD) initiated a project to promote responsible practices in public debt (Note 3). Nevertheless, UNCTAD's contribution (UNCTAD, 2012) is purely normative, renewing a number of principles of international law such as transparency, sovereignty, good faith, coordination, and cooperation between lenders and borrowers in the event of a crisis. It must be noted that these principles, which are not binding in nature, remain limited in scope.

In recent years, this awareness of the stakes involved in the sustainability issue has become more and more evident. Numerous United Nations' conferences and resolutions (Note 4) culminated in September 2015 in the adoption of the resolution A/RES/69/319 (Note 5) on Basic Principles on Sovereign Debt Restructuring Processes. In addition to the traditional principles that were reiterated, the resolution emphasized the concept of sustainability as a fundamental principle of the public debt management process. According to this principle, restructuring negotiations should lead to debt stabilization, while safeguarding the rights of creditors and promoting economic growth and sustainable development of the debtor country. The UN resolution places the issue of debt sustainability in its multidimensional context, by defending the objectives of minimizing socio-economic costs, guaranteeing the stability of the international financial system and respect for human rights.

The main objectives of this contribution are: (1) to analyze the social sustainability approach of external public debt in the MENA countries' framework; (2) to investigate the indicators on which this approach could be based; 
and (3) to evaluate to what extent that external debt might be a burden on an economy, i.e. the payment of the debt service might tend to crowd out public expenditures that affect the population living conditions. In other words, debt repayment absorbs resources that are intended to finance public expenditures that could have an impact on the population well-being, (Idlemouden \& Raffinot, 2005).

In the framework of MENA countries, there are few studies that analyzed the external public debt consequences on the population. In a paper entitled The Political Economy of Public Debt Sustainability in Turkey, Gurbuz (n.d.) applied the approach of Berr and Combarnous (2007) to the Turkish case and pointed out that a debt process can lead to interest asymmetry between creditors and debtors. In the literature, studies have generally explored the public debt sustainability hypothesis in a purely accounting view. Therefore, this paper will be one of the first contributions investigating the social sustainability of the external public debt in the MENA countries.

Nowadays, the social sustainability analysis of the external public debt of MENA countries is more than necessary since these economies had faced major socio-political instability during several years. Such a study c o u ld help the national authorities to define new debt management strategies and policies. It could also enrich theoretical and empirical research on the public debt by considering new dimensions adapted to current issues. Furthermore, the study highlights the different management approaches that are being adopted in the context of these countries.

The paper is divided into three sections. The first section introduces and analyzes the literature related to the public debt sustainability. The second one discusses the methodology adopted in both the statistical and econometric studies performed. In the last section, the main results are presented and interpreted. Finally, the conclusion summarizes the main findings and highlights some implications of the study.

\section{Literature Review: Towards a Social Approach to Public Debt Sustainability}

At the theoretical level, research on the social sustainability of public debt is very recent. Indeed, the relationship between external debt and the population living conditions has rarely been the main concern in the economic literature. The historical origin of this question can be found in the work of Keynes (1920), as well, as in that of the Post-Keynesian school (Berr \& Combarnous, 2007). The latter school study the expanded transfer capacity, i.e. the maximum income that the country can transfer abroad without affecting the standard of living of its population (Poulon, 1985).

However, the dominant economic approach of debt sustainability is based on analyzing the gap between the economic growth rate and the interest rate on public debt, named the critical gap. In fact, debt is a problem only if the real interest rate is higher than the growth rate (Aglietta, 2011; Sterdyniak, 2015).

Indeed, when the interest rate on the public debt is higher than the economic growth rate, the condition of public debt sustainability implies a short-term consolidation of public finance. Nevertheless, a vicious circle can be established when the budgetary effort leads to a decline in the economic growth rate. This will make the path of the future public debt unsustainable. On the contrary, when the public debt interest rate is lower than the growth rate, the public debt is sustainable. The growth rate of future tax revenues is higher than that of the debt service.

Despite its relevance and legitimacy, the critical gap analysis is called into question, especially for its theoretical foundation based on the scrupulous respect of the solvency condition. According to this purely accounting view of public indebtedness, only the repayment capacity of the debtor is privileged in the financing decision (Hanlon, (2000, 2002, 2006 \& 2007); Ramasastry, 2007; Merckaert \& Caliari 2007). Moreover, the social, cultural, political, and ecological impact on the populations involved in the public debt repayment process are totally ignored.

On the creditor side, the main question answered by the critical gap approach is whether the economic growth rate ensures the payment of the debt service. Meanwhile, on the debtor side, the critical gap approach indicates whether the contracted public debt benefits in terms of wealth creation is higher than its costs. The reasoning on both sides seems rather hasty and relatively too aggregated since all distribution problems are hidden.

The proponents of the liberal approach consider the United Nation proposals unrealistic (Destais, $2015 \mathrm{a}$ ) and the idea of a universal regime for sovereign debt restructuring illusory (Destais, $2015 \mathrm{~b}$ ). The liberal current, which justifies the sovereign debt crisis by shortcomings in the contractual approach seems to have little credibility. The current proposals of the liberal movement remain overall not very innovative (Note 6) (Destais, $2015 \mathrm{a} \& \mathrm{~b}$ ). At this level, it is important to underline that Fitoussi and Stiglitz (2012) have severely criticized the policies pursued by European countries for the management of the sovereign crisis. They reproach them for their very partial vision of sustainability, namely that of public debt, which has led to austerity programs that could ultimately lead to the financial non - sustainability of both the public and private sectors. Opponents of this current believe that the 
capitalist system has demonstrated its limits. They argue that it is time to reflect on alternative approaches in consultation with all the actors on the international scene.

Nowadays it must be acknowledged that alternative proposals have not reached the maturity required to propose effective, sustainable, and operational solutions to the sovereign debt problem. Nevertheless, they had the merit of broadening the debate to include social considerations. This study takes into consideration the social sustainability approach to public debt. It should be part of the new reflections on social progress and well-being initiated by the Stiglitz-Sen-Fitoussi report, (2010). New work and new statistical systems "should tell us whether or not what we are doing is economically, ecologically, politically and socially sustainable"(Fitoussi and Stiglitz, 2012 \& 2013). Thus, without seeking to provide definitive answers, the work of the "Stiglitz" Commission has rather contributed to the debate (Blanchet, Le Cacheux \& Marcus, 2009).

The report of the United Nations independent expert (2009) takes up this idea of debt sustainability based on the definition of a trade-off between debt servicing and a minimum level of public expenditures for the benefit of the population. The report is quite explicit on the issue. It suggests that "any concept of debt sustainability should include an assessment of the minimum amount of expenditures necessary for a government to meet its obligations to its citizens, including the provision of basic social services such as health and education". However, he seems to go beyond this purely accounting and relatively reductionist view of debt sustainability, adding that "human rights should be used as a criterion for assessing debt sustainability and cancel all unsustainable debts".

The most widespread idea of unsustainable debt is that of a debt whose repayment has over time become problematic. Indeed, the concept of non - sustainability is quite often reduced to situations where debt servicing becomes so excessive as to condemn the population concerned to impoverishment and worsening living conditions (health, public education, unemployment, undernourishment, etc.). Raffinot (2013) describes this situation as follows: Social sustainability"approaches are based on the idea that the level of debt (quite often debt service) can become excessive and force to reduce expenditures deemed necessary".

Nowadays, it is more than necessary to reconsider the purely accounting view of debt sustainability, by questioning the methodological choices and measurement tools. "Traditional" public debt indicators seem to be losing their relevance as the sovereign debt crisis deepens. Developed according to an asymmetrical construction considering only one point of view that of the creditors, the official indicators have become insufficient or even obsolete.

Studies are accustomed to analyzing the severity of public debt from the perspective of creditors only. In addition, it should be recalled that the international financial institutions provide support and assistance to countries that are unable to meet their constraints as debtors vis-à-vis creditors. Such theoretical analysis does not consider the indebtedness consequences on the population of indebted countries. Consequently, this partial and asymmetric approach remains insufficient. It must be complemented by the analysis of new indicators that consider the social situation of the population in the debtor countries. In other words, the impact of debt repayment on the living conditions of the countries' populations should not be overlooked. Thus, this study affirms the importance of jointly considering the interests of both parties concerned with the analysis of debt problems. If a country has the financial conditions that allow it to meet its commitments to lenders, the consequences of debt repayment on its population may jeopardize its solvency over time. For this reason, it is useful to analyze the usual indicators' evolution with comparison to that of the new indicators likely to enrich the consideration of the debt problem.

\section{Data and Methodology}

This study investigates the debt social sustainability in some MENA countries during 1990-2018 period with regression analysis. The questions asked are the following: (1) What is the sustainability of public debt, particularly in countries where public finance imbalances risk undermining the choices of national authorities regarding public expenditures and revenue? (2) Are levels of external public debt in some MENA countries socially sustainable?

The research hypotheses are: (a) the public debt solvency approach does not take into consideration the consequences of excessive external debt on the social welfare of the population in the indebted countries; (b) the public debt situation in the MENA countries is not socially sustainable; and (c) the public debt situation differs from one country to another.

\subsection{Data Description}

The study conducts a dual statistical and econometric analysis to examine the impact of external public debt on the social well-being of the population. The data used comes from two sources: (1) the annual reports of the national institutions of the countries studied, i.e. Central Banks and Ministries of Finance; and (2) data published by the World Bank. Data vary from 1990 to 2018 and cover the following MENA countries: Egypt, Lebanon, Morocco, Tunisia, and Turkey. 
Public debt in this research means the central government's debt issued in a foreign currency to finance public deficits. The study does not make a distinguishing between sovereign debt (Roos, 2019), government debt, public debt, or national debt, (Abbas, Pienkowski \& Rogoff, 2019).

Moreover, the study is only interested in the external debt issued in the international financial markets as well as borrowings from international financial institutions (World Bank, European Investment Bank, African Development Bank, etc.), bilateral loans, and loans from foreign commercial banks. Indeed, the choice of the external public debt issued in foreign currencies seems to be more relevant in the specific case of MENA countries. In fact, in these economies, central government debt is mostly external since the domestic market financing capacity is limited. Moreover, only the reimbursement of foreign debt service that could pose a problem of social sustainability.

\subsection{Statistical Analysis}

The statistical analysis aims at examining the evolution of the social sustainability indicators developed by Berr \& Combarnous (2007) in the MENA countries selected. Moreover, the study compares this evolution with that of the usual public debt ratios to show the importance of considering the social dimension of sustainability. Indeed, the public debt's analysis based on the usual indicators is inadequate. It must be complemented by an analysis of public debt from the perspective of the debtor countries. Therefore, the implementation of a multidimensional debt indicator is needed. In this study, the Debt Sustainability Indicator (DSI) used is that developed by Berr \& Combarnous (2007), which assesses the complexity and consequences of external public debt on the populations of indebted countries. The DSI is based on the methodology used by the United Nations Development Programs to construct the Human Development Index (HDI). In fact, the DSI takes into consideration three essential aspects: (1) the capacity of indebted countries to meet their financial commitments; (2) the effective burden of the "social burden" of debt on the populations of the countries concerned; and (3) the substitutability of debt repayment for both economic and human development.

To calculate the DSI, Berr \& Combarnous (2007) propose new multidimensional indicators integrating the impact of the burden of reimbursements on the well-being of the current populations and the living conditions of future generations. These indicators contribute to improving the perception of the debt social sustainability. More specifically, they aim to assess the extent to which external debt repayment is a substitute for other expenditures considered pro-development. In fact, the purpose of these indicators is to assess how much the debt servicing could limit a country's development opportunities by substituting to other, more beneficial uses such as investment, education, or public health. The variables put forward by Berr \& Combarnous, (2007) are summarized in table 1.

Table 1. Debt sustainability Indicators

\begin{aligned} \hline Indicators & \multicolumn{1}{c}{ Description } \\ \hline SDIK & Debt Service to Investment \\ SDPED & Debt Service to Public Education Expenditures \\ SDPSA & Debt Service to Public Health Expenditures \\ SDEX & Debt Service to Exports \\ SDHA & Debt Service per Capita (Note 7) \\ SDDT & Debt Service to Total Development Expenditures (Note 8) \\ SDPDH & Debt Servicing to Total Public Expenditures on Human Development (Note 9) \\ ISD & Debt Sustainability Indicator (Note 10). \end{aligned}

Note. Indicators developed by Berr \& Combarnous, 2007.

The dimensional indices are determined each time through a range of variation, with a minimum and a maximum. The extreme values used for the calculation are $[0.5,80]$ for the variable SDEX, [5, 3000] for SDHA, [0.01, 2] for SDIK, and $[0,4]$ for SDPDH. This choice is dictated by a principle of maximum spreading of the indices in their range of variation $([0,1])$, it then makes it possible to measure them by simple linear interpolation. The debt sustainability indicator noted ISD corresponds to the arithmetic mean of these three-dimensional indices. 


\subsection{Econometric Analysis: Estimation Using the ARDL Panel Model}

The study adopts the methodology based on estimation using the Auto Regressive Distributed Lag(ARDL) dynamic panel model, which allows to analyze both the short- and long-term relationship between the variables. This approach has been developed by Pesaran et al, (2001). It has been found to be appropriate for examining longterm relationships in small sample sizes. Moreover, it has the particularity of considering the temporal dynamics. Its application does not require that all variables be integrated of order 1 (I (1)) as indicated by Johansen (1988, 1991, 1995). However, the implementation of this approach requires the prior analysis of panel stationarity of the data. The study, use the Levin, Lin, \& Chu, (LLC); Im, Pesaran, \& Shin, (IPS); Augmented Dickey-Fuller, (ADF); Philips Perron (PP); and Breitung test (B-t) panel unit root tests, (Choi, 2001; Hadri, 2000; Im, Pesaran, Shin, 2003; Levin, Lin, \& Chu; 2002; Breitung \& Das, 2005). Table 2 summarizes the variables used in econometric analysis.

Table 2. Variables description

\begin{tabular}{|c|c|c|}
\hline Variable & Definition & Description \\
\hline GDPCAP & GDP per Capita & $\begin{array}{l}\text { Measuring the level and social living conditions of the } \\
\text { population. }\end{array}$ \\
\hline EXDP & Public external debt ratio & Measuring the weight of the external public debt on GDP \\
\hline INVGDP & Investment ratio & Measured by the investment percentage of GDP \\
\hline TERMS & The terms of trade & $\begin{array}{l}\text { Measured by the ratio of the unit value index of exports to } \\
\text { the unit value index of imports (Note 11) }\end{array}$ \\
\hline
\end{tabular}

Note. all variables are expressed in their logarithm.

\section{Results and Discussions}

\subsection{Statistical Analysis}

\subsubsection{Results of the New External Public Debt Indicators}

\section{a. Debt Service per Capita (SDHA)}

This indicator measures the actual burden of public debt service on the populations of the debtor countries considered. Indeed, its average value differs from one country to another. This situation shows that countries have different debt management policies. The average SDHA of the countries studied fluctuates between 187.66 USD (PPP) and 277.97 USD (PPP) between 2002 and 2018. These levels represent in 2002 and 2018, respectively 2.05\% and $1.14 \%$ of the countries' GDP per capita (PPP). However, the observation of figure 2 shows that Tunisia and Turkey have shares of service debt in GDP per capita that exceed the average of the study sample. On the other hand, those of Morocco, Lebanon and Egypt are below this level. This result allows to conclude that external debt service weighs more on the population in Tunisia and Turkey than in the other countries in the sample.

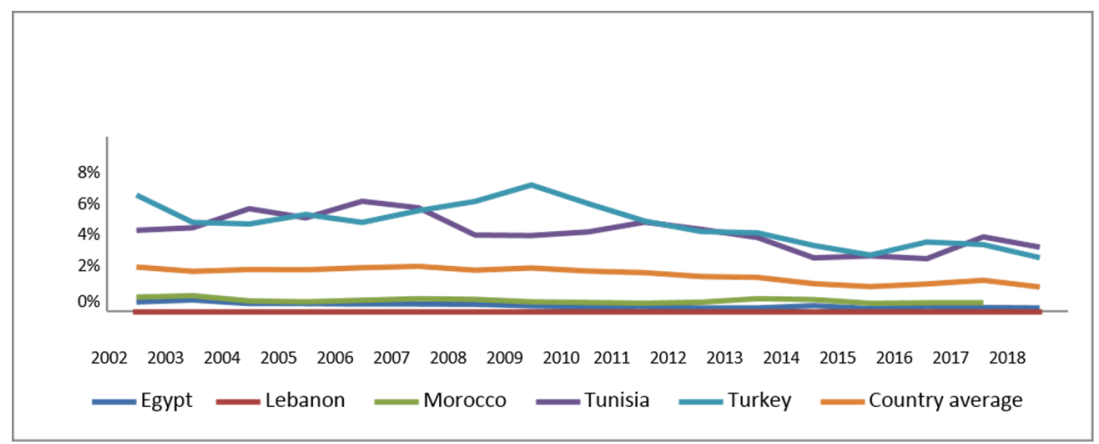

Figure 2. Evolution of the SDHA Share in GDP per Capita in MENA countries (Note 12)

\section{b. Debt Service to Investment (SDIK)}

The Debt Service to Investment (SDIK) represents the amount of public debt service in relation to the amount of public expenditures devoted to financing public investment. It provides information on the burden of external 
public debt servicing on the development of countries. The higher this indicator is, the more the debt service burden is penalizing for public investments.

Figure 3 shows that the average SDIK of the countries studied is at a level of 0.37 during the study period. It represents $37 \%$ of the investment in the countries studied. However, the analysis shows another situation that reflects a difference in the public finance policies of the countries. The comparison of the average of this indicator between countries indicates that Lebanon occupies the first place compared to the other countries in the sample. Indeed, the average level of the SDIK in Lebanon between 2002 and 2018 represents an amount higher than the budget allocated to investment. In the case of the other countries, it is below the sample average. This result proves that the servicing of the external public debt weighs heavily on the expenditures allocated to public investment.

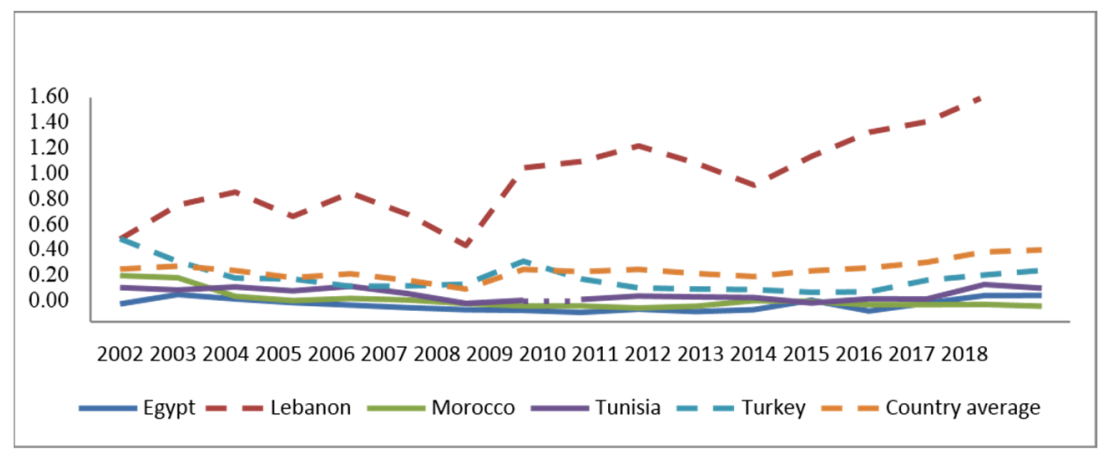

Figure 3. Evolution of the SDIK in MENA countries

\section{c. Debt Service to Public Health Expenditures (SDPSA)}

Figure 4 demonstrates that the average SDPSA for the five MENA countries in the sample stands between 2002 and 2016 at a level of 1.80. This result means that the external public debt service exceeds 180 percent of the budget allocated to public health. However, in Lebanon, the average SDPSA during the reporting period is at a level of 3.74. This result shows the low share of public expenditures on public health in the total budget. Morocco occupies the second position with an average SDPSA of 2.01. It should be noted that this country has managed to gradually lower the level of this indicator since 2002. It must be noted that Turkey spends more public money on health than the other countries in the sample.

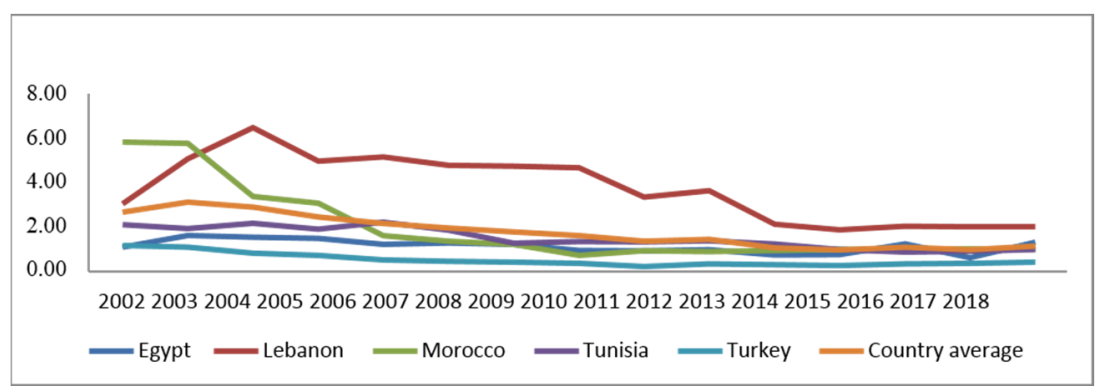

Figure 4. Evolution of the SDPSA in MENA countries

\section{d. Debt Service to Public Education Expenditures (SDPED) (Note 13)}

According to available statistics, the Debt Service to Public Education Expenditures (SDPED) is about 0.54 between 2003 and 2008 in Egypt. In Tunisia, it was at the level of 0.82 between 2002 and 2009. While it reaches 0.56 in 2015. In the case of Turkey, the SDPED represents 1.10 between 2002 and 2006. In Morocco, it recorded 0.43 between 2008 and 2009. In Lebanon, the SDPED was at the level of 6.01 between 2002 and 2013. Moreover, it can be noted that in Lebanon the SDPED far exceeds unity, with external debt servicing much higher than the amount of the budget allocated to public education. It must be said that it is difficult to make a reliable comparison between these countries given the absence of official statistics on this indicator.

\subsubsection{Comparative Analysis of Current and New Indicators}

The comparative analysis of the usual (SDPEX, SDPIB) and new (SDHA, SDIK, SDSPA) debt indicators, reflects the stakes of the public debt. The first indicators analyze the severity of debt from the creditors' perspective. While 
those put forward by Berr and Combarnus (2007) examine the debt situation from the debtors' point of view. While the former approach omits the social issues of the public debt, the latter focus on the indebted countries' capacity to meet their financial commitments, with respect to the social constraints.

Figure 5 shows the following facts:

(1) The usual indicator of debt service in relation to exports (SDEX) shows a continuous favorable trend between 2002 and 2008. However, the trend is reversing, with an unfavorable situation from 2008 to 2018.

(2) As for the indicator of the social burden of external public debt (SDHA), it shows a steady deterioration between 2003 and 2007. Thereafter, it evolved favorably, declining from 2008 to 2015 . However, it shows a further deterioration from 2015 to 2017 . This fluctuation can also be explained by the evolution of countries' GDPs.

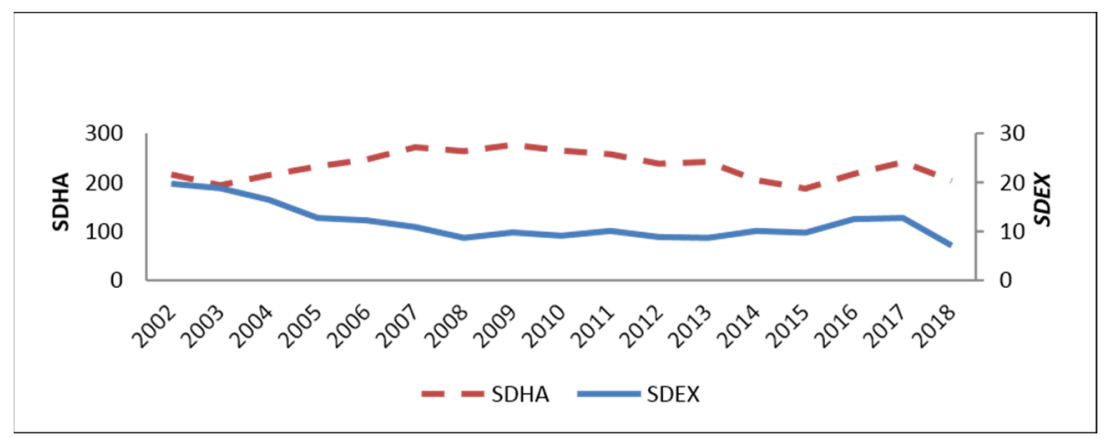

Figure 5. Comparison of average values of SDHA and SDEX (MENA - 2002-2018)

Figure 6, which illustrates the evolution of the averages of the indicators (SDIK and SDEX), makes it possible to elucidate the following remarks:

(1) The debt-service-to-exports ratio (SDEX) indicator has been favorable from 2002 to 2018. Admittedly, there is a slight fluctuation between 2008 and 2017. However, with a comparison to its evolution during this 2008-2018 period with that of 2002, the SDEX has evolved positively.

(2) As for the Debt Sustainability Indicator for Economic Development (SDIK), since 2008, it has shown an upward trend characteristic of a worsening of the average situation of indebted countries. Between 2002 and 2008, it fluctuated, but showed a downward trend, reflecting a slight improvement in their average situation. The general evolution of the indicator (SDIK) reflects the adverse political situation of countries on investment, especially from 2010 onwards.

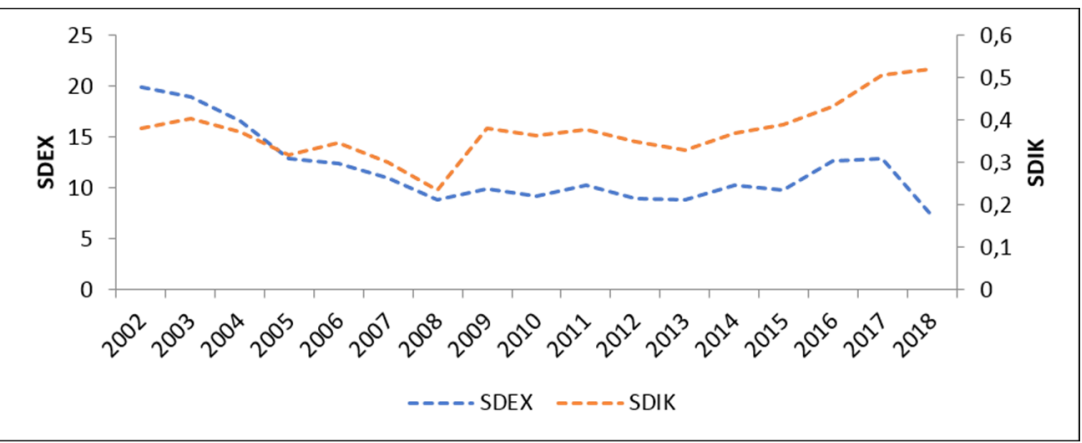

Figure 6. Comparison of average values of SDIK and SDEX (MENA - 2002-2018)

Figure 7 presents a comparison between changes in public debt service in relation to exports (SDEX) and the debt sustainability indicator for human development (SDPSA). It shows the following remarks:

(1) The indicator (SDPEX) shows a very favorable situation between 2002 and 2008. Thereafter, it fluctuates sometimes upwards and sometimes downwards, while recording an upward trend reflecting an unfavorable situation compared to the first period (2002 - 2008).

(2) As far as the evolution of the indicator (SDPSA) is concerned, it shows a favorable situation over the period (2002-2016). 


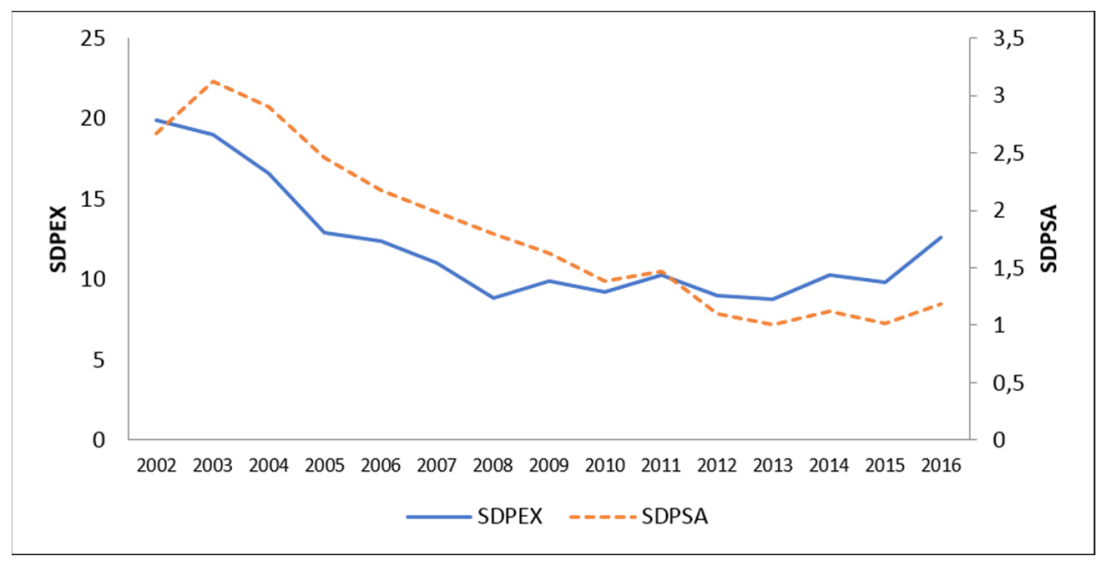

Figure 7. Evolution of average values of SDPEX and SDPSA (MENA - 2002-2018)

The absence of data on the indicator (SDPED) over the entire period does not allow to make a comparison of its evolution between countries. However, observation of the statistics for this indicator shows that Lebanon is in an unfavorable situation compared with all the other countries in the sample. Indeed, the average value of this indicator between 2004 and 2008 is at the level equal: 6.715 for Lebanon, 0.535 for Egypt and 0.834 for Tunisia.

The comparisons between the usual and the new debt indicators reveal the need to consider the debtor's point of view in measuring the seriousness of the international debt problem. Moreover, it must be noted that the social sustainability approach is complementary to the creditors' point of view and does not replace the latter. This result motivates the production of multidimensional debt indicators that allow the best possible synthesis of the interests of creditors and debtors.

\subsubsection{Comparative Analysis of ISD (Note 14) and SDEX Levels}

The multi-dimensional indicator (ISD) provides a picture of the debt problem from the perspective of both creditors and debtors. Its main objective is to enrich the approach to public debt management. While the ratio (SDEX) makes it possible to judge the size of the debt from the point of view of creditors' interests. A comparative analysis of the two indicators SDEX and ISD shows that their evolution during the period 2002-2018 is fluctuating and does not follow the same direction in the countries studied. The situation differs from one country to another. However, the general trend of social non-sustainability of public debt remains the same in these countries.

As regards the Lebanese case, Figure 8 shows a parallel evolution of the two indicators and the higher levels of the ISD compared to those of the SDEX ratio during the 2002-2013 period, except for the 2002 year. The downward trend in the SDEX ratio is more pronounced than that of the ISD indicator. This means that public debt service is falling relative to exports (a good sign for lenders), but it represents a higher social cost (a bad sign for debtors). This leads us to conclude that if the debt is sustainable regarding the indicator (SDEX), it is unsustainable from the point of view of the population's capacity to bear it (ISD).

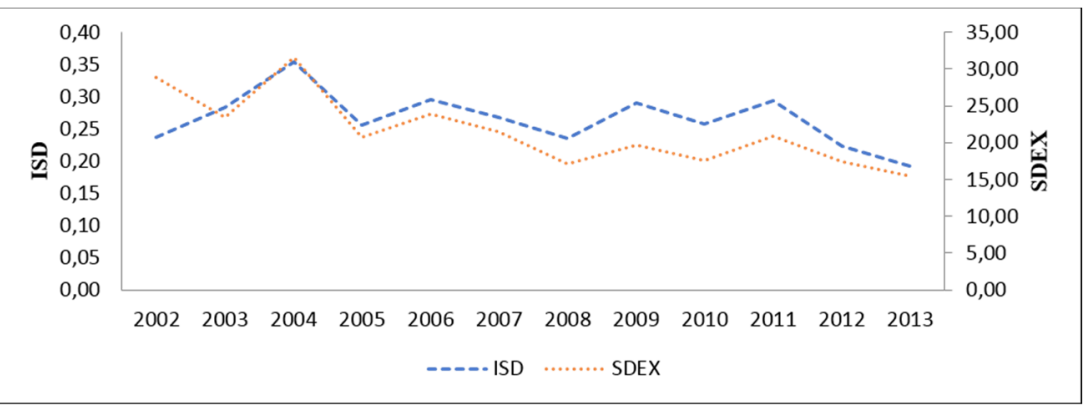

Figure 8. Comparison of the evolution of the ISD and SDEX in the Lebanese context (2002-2018)

Regarding the Egyptian case, Figure 9 shows a downward trend in the evolution of the two indicators (ISD and SDEX). It seems that the debt sustainability indicator is relatively higher than the SDEX indicator over the period 
(2003-2008), except for 2003. It should be recalled that the ISD higher level compared to the SDEX ratio compromises the social sustainability of the public debt in Egypt.

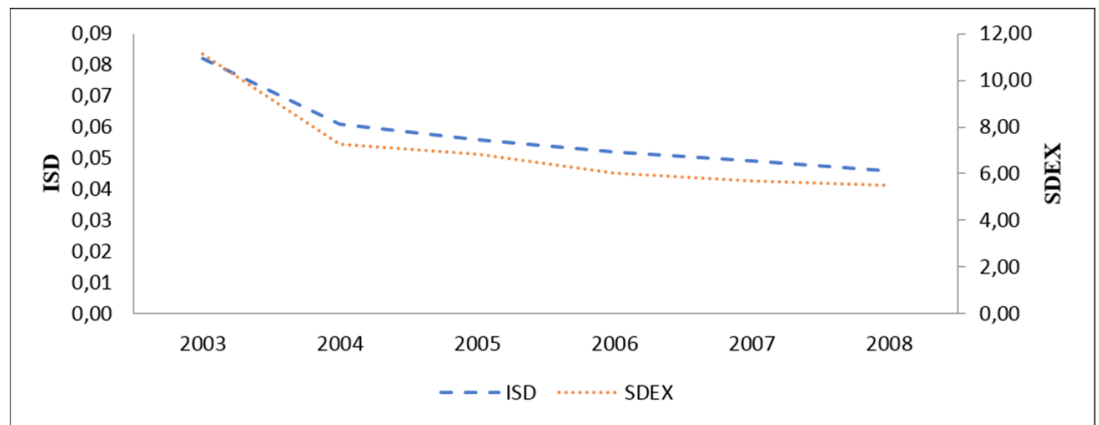

Figure 9. Comparison of evolution of the ISD and SDEX indicators in the Egyptian context (2002-2019)

For the Tunisian case, the Figure 10 reveals that the evolution of the two ratios is relatively parallel. However, between 2006 and 2008, the social sustainability of the Tunisian debt is in question. Moreover, Figure 10 shows that the ISD resumes its upward trend since 2011, while remaining below the 2012 level.

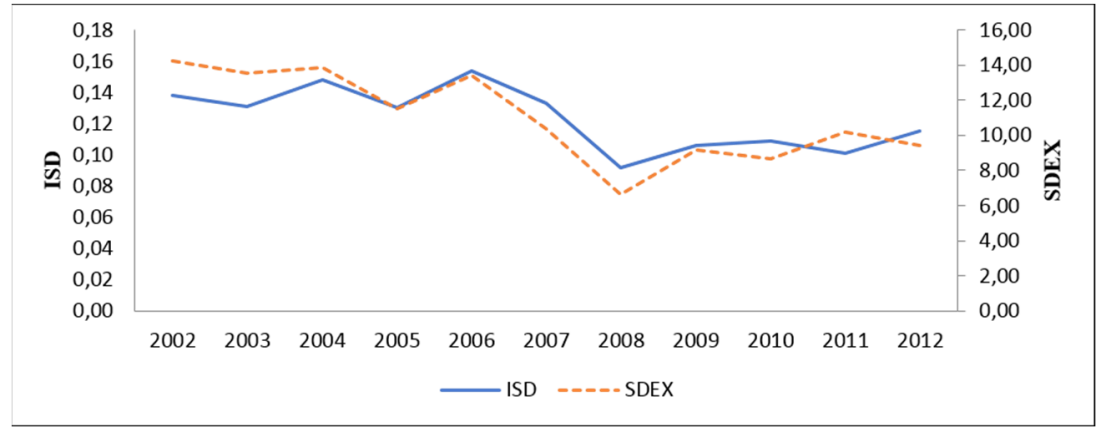

Figure 10. Comparison of evolution of the ISD and SDEX indicators in the Tunisian context (2002-2019)

In the case of Turkey, Figure 11 establishes that the ISD indicator shows a downward trend between 2002 and 2004. From 2004 onwards, it increased. However, this graph reflects that the SDEX ratio is on a downward trend between 2002 and 2006. The level of SDI is higher than the SDEX ratio in 2002 and between 2004 and 2006. This situation highlights that the social sustainability of public debt is compromised in Turkey during these years. In the case of Morocco, it can be noted that the comparison of ISD and SDEX levels between 2008 and 2009 shows that both indicators show a decrease in 2009 compared to 2008. However, the SDI remains higher than the SDEX ratio. This allows us to raise the issue of the social sustainability of Morocco's public debt.

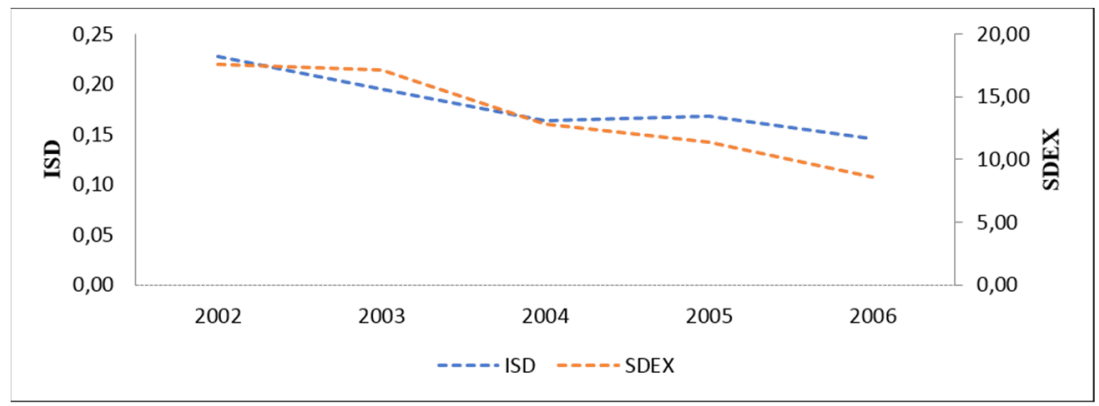

Figure 11. Comparison of evolution of the ISD and SDEX indicators in the Turkish context (2002-2006)

The comparison of the levels of ISD and SDEX between the countries reveals that the social unsustainability of public debt in Lebanon is more pronounced than in the other countries. However, in all the countries of the sample, the additional debt from one year to another is intended to finance the servicing of past public debt instead of social public expenditures mainly those of education and health. 


\subsection{The Econometric Study}

The econometric study's objective is to determine the impact of external public debt on the living conditions of the populations involved in the process of its repayment. Thus, using the ARDL panel data estimation technique, the long-term and then short-term relationships between public debt and standards of living are estimated. Public debt is measured by external public debt as a percentage of GDP. While the standards of living are estimated by GDP per capita.

\subsubsection{Stationarity Analysis}

Analysis of the stationarity (or non-stationarity) of variables (Note 15) is a requirement for applying the statistical properties of estimation methods. The development of unit root tests in panel data has taken place since the early 1990s. In these tests, the determination of the asymptotic properties of the estimators and the tests proposed for non-stationary panels requires the size of the individual and temporal dimensions. Indeed, the unit root test is performed to ensure that no variable integrated of order 2, I (2) is included.

This condition is essential because the ARDL estimation procedure assumes that all variables are integrated of order I ( 0 ) or I (1). In other words, if a variable is integrated of order 2, I (2), the calculated F statistics produced by Pesaran et al. (2001) cannot be validated. The stationarity tests results are presented in table 3 .

Table 3. Stationarity test at 5\% significance level

\begin{tabular}{|c|c|c|c|c|c|c|c|c|c|}
\hline & \multicolumn{3}{|c|}{ Statistics } & \multicolumn{3}{|c|}{ P-Value } & \multicolumn{3}{|c|}{ Stationarity } \\
\hline Variables & (a) & (b) & (c) & (a) & (b) & (c) & (a) & (b) & (c) \\
\hline \multicolumn{10}{|c|}{ LNGDPCAP } \\
\hline LLC & -1.83777 & 2.02836 & 5.82029 & 0.0330 & 0.9787 & 1.000 & Yes & No & No \\
\hline B t-stat & - & 0.06580 & - & - & 0.5262 & - & - & No & - \\
\hline IPS & 0.88403 & 1.48419 & - & 0.8117 & 0.9311 & - & No & No & - \\
\hline ADF-F & 5.88780 & 6.02082 & 0.37957 & 0.8246 & 0.8135 & 1.000 & No & No & No \\
\hline PP-F & 16.4766 & 15.8776 & 0.11789 & 0.0868 & 0.1032 & 1.000 & No & No & No \\
\hline \multicolumn{10}{|l|}{ LNEXPD } \\
\hline LLC & -0.37258 & 0.83931 & -1.17208 & 0.3547 & 0.7994 & 0.1206 & No & No & No \\
\hline B t-stat & - & 0.26925 & - & - & 0.6061 & - & - & No & - \\
\hline IPS & 0.43101 & 0.60994 & - & 0.6668 & 0.7289 & - & No & No & - \\
\hline ADF-F & 8.15703 & 7.76097 & 9.37981 & 0.6135 & 0.6522 & 0.4965 & No & No & No \\
\hline PP-F & 7.79970 & 6.52088 & 9.95929 & 0.6484 & 0.7698 & 0.4441 & No & No & No \\
\hline \multicolumn{10}{|l|}{$\underline{\text { LNINGDP }}$} \\
\hline LLC & 0.57258 & 0.09141 & -0.96059 & 0.7156 & 0.4636 & 0.1684 & No & No & No \\
\hline B t-stat & - & -1.22670 & - & - & 0.1100 & - & - & No & - \\
\hline IPS & 0.91241 & -2.12388 & - & 0.8192 & 0.0168 & - & No & Yes & - \\
\hline ADF-F & 0.02047 & 21.0372 & 10.1082 & 0.8898 & 0.0208 & 0.4310 & No & Yes & No \\
\hline PP-F & 0.57065 & 7.22872 & 9.05162 & 0.8500 & 0.7038 & 0.5272 & No & No & No \\
\hline \multicolumn{10}{|c|}{ LNTERMES } \\
\hline LLC & 0.63191 & -1.07681 & 1.24530 & 0.2637 & 0.1408 & 0.8935 & No & No & No \\
\hline B t-stat & - & -2.49564 & - & - & 0.0063 & - & - & Yes & - \\
\hline IPS & 0.28714 & -1.00278 & - & 0.6130 & 0.1580 & - & No & No & - \\
\hline ADF-F & 6.19899 & 14.3130 & 2.83866 & 0.7983 & 0.1592 & 0.9850 & No & No & No \\
\hline PP-F & 4.30658 & 11.9846 & 6.48542 & 0.9325 & 0.2861 & 0.7730 & No & No & No \\
\hline
\end{tabular}

Note. Authors' calculations using Eviews 8; Variables in logarithms; P-V: P-Values/ Method definitions : LLC=Levin, Lin, Chu t* ; IPS= Im, Pesaran, Shin w-stat; ADF-F= Augmented Dickey - Fuller-Fisher Chi Square; PP-F= Philips, Perron; Fisher;Chi Square; B-tS= Breitung; t-stat /(a) Constants with no trend; (b) Constant and trend; (c) Neither trend nor constant 
The stationarity tests results show that at the 5\% significance level, most tests for each variable are not significant. This indicates that not all variables are stationary in level. Therefore, it is then necessary to carry out the stationarity test using their primary difference.

The results of the first difference stationarity tests are summarized in table 4 . The first difference stationarity analysis shows that the value of the statistics is below the critical value, which leads to reject the null hypothesis of non- stationarity at the $5 \%$ significance level. This means that all the selected variables are therefore integrated of order 1. Consequently, no series is integrated of order two I (2). This allows for the application of the ARDL model in the framework of the countries of the sample.

Table 4. First difference stationarity test at 5\% significance level

\begin{tabular}{|c|c|c|c|}
\hline Variables & $\begin{array}{c}\text { Statistics } \\
\text { (c) }\end{array}$ & $\frac{\text { P-Value }}{\text { (c) }}$ & $\begin{array}{c}\text { Stationarity } \\
\text { (c) }\end{array}$ \\
\hline \multicolumn{4}{|l|}{ D(LNGDPCAP) } \\
\hline LLC & -6.43652 & 0.0000 & Yes \\
\hline B t-stat & - & - & - \\
\hline IPS & -8.19872 & 0.0000 & Yes \\
\hline ADF-F & 73.8362 & 0.0000 & Yes \\
\hline PP-F & 91.5565 & 0.0000 & Yes \\
\hline \multicolumn{4}{|l|}{$\underline{\text { D(LNEXPD })}$} \\
\hline LLC & -7.25853 & 0.0000 & Yes \\
\hline B t-stat & - & - & - \\
\hline IPS & -6.73798 & 0.0000 & Yes \\
\hline ADF-F & 59.3521 & 0.0000 & Yes \\
\hline PP-F & 59.2434 & 0.0000 & Yes \\
\hline \multicolumn{4}{|l|}{$\underline{\text { D(LNINGDP) }}$} \\
\hline LLC & -7.80962 & 0.0000 & Yes \\
\hline B t-stat & - & -0.0000 & - \\
\hline IPS & -7.14156 & 0.0000 & Yes \\
\hline ADF-F & 63.5375 & 0.0000 & Yes \\
\hline PP-F & 63.7505 & & Yes \\
\hline \multicolumn{4}{|l|}{ D(LNTERMES) } \\
\hline LLC & -7.53210 & 0.0000 & Yes \\
\hline B t-stat & - & -0.0000 & - \\
\hline IPS & -8.22794 & 0.0000 & Yes \\
\hline ADF-F & 74.5984 & 0.0000 & Yes \\
\hline PP-F & 89.3164 & & Yes \\
\hline
\end{tabular}

\subsubsection{Results of the ARDL Estimation in First Difference}

According to Pesaran et al (2001), several studies have highlighted the simplicity of the ARDL approach, which makes it possible to analyze the nature of the long- and short-term relationship between the different variables.

a) The Long-Term Relationship

The results summarized in table 5 show that the coefficient on the variable (EXPD) is negative. This result is consistent with theoretical and empirical predictions. The sign of this coefficient is negative and highly significant $(\mathrm{P}-\mathrm{Value}<5 \%)$. This result is expected given the size of the public debt and its negative impact on the population's standard of living. For the variable (INVGDP), the coefficient is positive and highly significant. This result is also expected since the public investment expenditures have a favorable impact on the population's standard of living. 
The sign of the coefficient of the variable (TERMS) is positive. The latter has a positive and significant effect (at the $10 \%$ threshold) on the population's standard of living.

Table 5. The long-term estimation

\begin{tabular}{lcccc}
\hline \multirow{2}{*}{ Variables } & \multicolumn{4}{c}{ Dependent Variable: D(LNDGPCAP,2) } \\
\cline { 2 - 5 } & Coefficient & Std. Error & t-Statistic & Prob. \\
\hline D(LNEXPD) & -0.045087 & 0.020691 & -2.179021 & 0.0317 \\
D(LNINVGDP) & 0.204397 & 0.041172 & 4.964514 & 0.0000 \\
D(LNTERMES) & 0.089176 & 0.052999 & 1.682607 & 0.0956 \\
\hline Log likelihood & 322.6083 & & & \\
\hline
\end{tabular}

Note. p-values and any subsequent tests do not account for model

The long -term relationship is the following:

$$
\mathrm{D}(\text { LNGDPCAP }) \mathrm{t}=-0.045087^{*} \mathrm{D}(\text { LNEXPD }) \mathrm{t}+0.204397 \mathrm{D}(\text { LNINVGDP }) \mathrm{t} .089176^{*} \mathrm{D}(\text { LNTERMS }) \mathrm{t}
$$

The long-term relationship reveals that the ratio of external public debt as a percentage of GDP has a negative effect on the standard of living of the population (GDPCAP). This means that if this ratio increases by $10 \%$, the standard of living of the population deteriorates by $4.5 \%$. This result can be justified by the fact that the external public debt has not benefited the population, but rather has been used to finance non-productive expenditures (notably debt servicing). This result converges with those obtained with the statistical approach performed previously. According to these results, the additional public debt is used to finance the previous public debt service instead of financing expenditures that have a positive impact on the population's standard of living. This situation contributes to compromising the social sustainability of public debt in the countries studied.

b) The Short-Term Relationship

The short-Term equation is the following:

$$
\begin{array}{r}
\mathrm{D}(\mathrm{D}(\text { LNGDPCAP })) \mathrm{t}=-0.737741 * \text { et- } 1-0.043438 * \mathrm{D}(\text { LNEXPD })(\mathrm{t}-1)-0.036934 * \mathrm{D}(\text { LNINVGDP })(\mathrm{t}-1) \text { - } \\
0.011155 * \mathrm{D}(\text { LNTERMES })(\mathrm{t}-1)+0.017567 \mathrm{C}
\end{array}
$$

The short-term coefficient of the EXPD variable has a negative and significant sign (P-Value is $<5 \%$ ). Indeed, the share of external public debt in GDP has a negative and significant effect on the living conditions of the population (as measured by GDP per capita). On the other hand, the coefficients of the variables (INVPIB and TERMS) have negative, but insignificant effects (P- Values $>5 \%$ ). As noted in table 6 , the coefficient of the recall force to equilibrium Coint $\mathrm{Eq}(-1)=-0.738$ is negative and significantly different from 0 , at the $5 \%$ level of significance. This reflects the existence of an error correction mechanism. This coefficient expresses the degree to which the GDPCAP variable will be recalled to the long-term target. It reflects a relatively rapid adjustment to the long-term target. In other words, the negative sign on the error-correction term confirms the expected convergence process in the long-term dynamics.

Table 6. The short-term estimation

\begin{tabular}{lcccc}
\hline \multirow{2}{*}{ Variables } & \multicolumn{4}{c}{ Dependent Variable: D(LNDGPCAP,2) } \\
\cline { 2 - 5 } & Coefficient & Std. Error & t-Statistic & Prob. \\
\hline COINTEQ01 & -0.737741 & 0.139779 & -5.277917 & 0.0000 \\
D(LNEXPD) (-1) & -0.043438 & 0.017983 & -2.415509 & 0.0175 \\
D(LNINVGDP) (-1) & -0.036934 & 0.091281 & -0.404624 & 0.6866 \\
D(LNTERMES) (-1) & -0.011155 & 0.025674 & -0.434472 & 0.6649 \\
C & 0.017567 & 0.004246 & 4.136881 & 0.0001 \\
\hline Log likelihood & 322.6083 & & & \\
\hline
\end{tabular}

Note. p-values and any subsequent tests do not account for model 


\section{Conclusion and Implications}

This study reveals that external public debt can have a negative impact on the population's standard of living. Even if the debt is not the only cause of the social situation deterioration (poverty, inequality, etc.), it contributes to its amplification. For this reason, it should be stressed that the approach to debt sustainability needs to evolve by taking into consideration the social constraints of the indebted countries. Very often, studies focus on sustainability analysis from the perspective of creditor countries. This approach is necessary, but it is not sufficient. It must be complemented by the issue of social sustainability. Indeed, public debt can lead to a situation of antagonism between the interests of debtor and creditor countries. In other words, debt may be sustainable in the creditors' point of view, but not of the indebted countries and vice versa.

The main contributions of this study are in two folds:

Firstly, the statistical analysis of the evolution of the new debt indicators and their comparison with the usual ones demonstrates that the distribution of public investment expenditures (SDIK, SDPSA and SDPED) is different from one country to another. However, in most of the countries in the sample, the external public debt service weighs heavily on the public expenditures allocated to investment. In other words, the external debt service is well more than the budget allocated for these expenses. The comparison between the two indicators (SDI) and (SDEX) in these countries shows that even if the debt is sustainable regarding the (SDEX) indicator, it is not necessary that will be so in terms of those countries' social capacity (SDI).

Secondly, the econometric study demonstrates that an increase in the debt ratio as a percentage of GDP (both in the short and long run) implies a decrease in the level of GDP per capita. This means that the population's standard of living is affected by the level of external public debt. In other words, public debt is one of the causes of poor health and education conditions in the MENA countries of the sample. In fact, the public debt service seems to crowd out public spending on education and health, which negatively affects the living population's conditions.

In this study, both statistical and econometric analyses highlight the need to consider the creditors and debtors' views to implement a comprehensive public debt approach that incorporates the complexity and social consequences of the issue. Nevertheless, further analysis is needed to clarify the social issues of external public debt in the current context. The new approaches must integrate not only health and education expenditures, but also those related to the environment and the physical infrastructure of countries. Such analyses will make it possible to ensure comprehensive management of the social dimensions of public debt. In addition, this study could be extended to the interior debt effects on growth and financial development (Ajili, Ayoub \& Raffinot, 2013).

In terms of economic policy, the study leads to some implications for public debt management in the MENA countries of the sample. Indeed; the study highlights the need for national authorities: (1) to ensure comprehensive management of public debt that considers both the creditors' interests and the capacity of the indebted countries to reimburse their debt; (2) to borrow only to finance the most productive investment expenditures, which can have a positive impact on the standard of living of the population and on economic growth; (3) to limit the implementation of austerity and anti-social policies.

\section{Acknowledgements}

The authors would like to gratefully acknowledge the financial support provided by the Lebanese University. Many thanks go to PR. Wadad SAAD for his invaluable comments on the econometric part of research.

\section{References}

Abbas, A. S., Pienkowski, A., \& Rogoff, K. (2019). Sovereign Debt: A Guide for Economists and Practitioners. Oxford, United Kingdom, Oxford University Press. https://doi.org/10.1093/oso/9780198850823.001.0001

Aglietta, M. (2011). Croissance durable : Mesurons-nous bien le défi ? (Sustainable Growth: Are we Measuring the Challenge?) Revue d'Économie du Développement, 19(2), 199-250. https://doi.org/10.3917/edd.252.0199

Ajili, W., Ayoub, H., \& Raffinot, M. (2013). Dette publique intérieure et développement financier dans le contexte des pays méditerranéens: cas du Liban et de la Tunisie. (Domestic Public Debt and Financial Development in the Context of Mediterranean Countries: the case of Lebanon and Tunisia). Techniques Financières et Dévelopement, 110(I), 45-65. https://doi.org/10.3917/tfd.110.0045

Berr, E., \& Combarnous, F. (2007). Une autre lecture de la soutenabilité de la dette. (Another Reading of Debt Sustainability). Revue Tiers Monde, 192, 789-813. https://doi.org/10.3917/rtm.192.0789

Blanchet, D., Le Cacheux, J., \& Marcus, V. (2009). Adjusted Net Savings and other Approaches to Sustainability: Some Theoretical Background, Working Paper, INSEE/DESE $n^{\circ}$ G 2009/10. November 2009. 
Breitung, J., \& Das, S. (2005). Panel Unit Root Tests under Cross-Sectional Dependence. Statistica Neerlandica, 59(4), 414-433. https://doi.org/10.1111/j.1467-9574.2005.00299.x

Chavagneux, C. (2012). Quel est le bon niveau de dette publique ? (What is the Right Level of Public Debt). L'Économie Politique, 55(3), 5-6. https://doi.org/10.3917/leco.055.0005

Choi, I. (2001). Unit Root Tests for Panel Data. Journal of International Money and Finance, 20(2), 249-272. https://doi.org/10.1016/S0261-5606(00)00048-6

Destais, C. (2015a). Restructuration des dettes souveraines : Comment sortir de l'ornière ? (Sovereign Debt Restructuring: How to get out of the Rut?) Lettre du CEPII, 357, 1-4.

Destais, C. (2015b). Restructuration des dettes souveraines : Le manque de réalisme de l'ONU. (Sovereign Debt Restructuring: The UN's Lack of Realism) La Tribune, September 2015. Retrieved from https://www.latribune.fr/opinions/blogs/le-blog-de-l-economie-internationale/restructuration-des-dettessouveraines-le-manque-de-realisme-de-l-onu-507578.html

Fitoussi, J. P., \& Stiglitz, J. E. (2012). Nouvelles réflexions sur la mesure du progrès social et du bien-être. (New Reflections on Measuring Social Progress and Well-being) Revue de l'OFCE, 120(1), 311-328. https://doi.org/10.3917/reof.120.0311

Fitoussi, J. P., \& Stiglitz, J. (2013). On the Measurement of Social Progress and Wellbeing: Some Further Thoughts. Global Policy, 4(3), 290-293. https://doi.org/10.1111/1758-5899.12072

Gurbuz, B. (n.d). Political Economy of Debt Sustainability in Turkey. Retrieved from www.academia.edu

Hadri, K. (2000). Testing for Stationarity in Heterogeneous Panel Data. The Econometrics Journal, 3(2), 148-161. https://doi.org/10.1111/1368-423X.00043

Hanlon, J. (2000). How much debt must be cancelled? Journal of International Development, 12(6), 877-901. https://doi.org/10.1002/1099-1328(200008)12:6<877::AID-JID720>3.0.CO;2-9

Hanlon, J. (2002). Defining illegitimate debt and liking its cancellation to economic justice. Open University for Norwegian Church Aid, June 2002.

Hanlon, J. (2006). Illegitimate loans: Lenders, not borrows, are responsible. Third World Quarterly, 27(2), 211226. https://doi.org/10.1080/01436590500432283

Hanlon, J. (2007). Wolfowitz, the World Bank, and illegitimate lending. The Brown Journal of World Affairs, XIII(2), 41-54.

Humbert, M. (2016). Dette stratosphérique et équilibre économique et social : Le paradoxe japonais. (Stratospheric Debt and Economic and Social Equilibrium: The Japanese Paradox) Savoir/Agir, March 2016(35), 45-52. https://doi.org/10.3917/sava.035.0045

Idlemouden, K., \& Raffinot, M. (2005), Le fardeau virtuel de la dette extérieure, (The Virtual Burden of External Debt) Working Paper ERISCO, $\mathrm{n}^{\circ}$ 2005-03.

Im, K. S., Pesaran, M. H., \& Shin, Y. (2003). Testing for Unit Roots in Heterogeneous Panels. Journal of Econometrics, 115(1), 53-74. https://doi.org/10.1016/S0304-4076(03)00092-7

Johansen, S. (1988). Statistical Analysis of Cointegration Vectors. Journal of Economic Dynamics and Control, 12(2-3), 231-254. https://doi.org/10.1016/0165-1889(88)90041-3

Johansen, S. (1991). Estimation and Hypothesis Testing of Cointegration Vectors in Gaussian Vector Autoregressive Models. Econometrica, 59(6), 1551-1580. https://doi.org/10.2307/2938278

Johansen, S. (1995). Likelihood-Based Inference in Cointegrated Vector Autoregressive Models. New York: Oxford University Press. https://doi.org/10.1093/0198774508.001.000

Keynes, J. M. (1920). The Economic Consequences of the Peace. New York, Harcourt, Brace and Howe.

Levin, A., Lin, C.-F., \& Chu, C.-S. J. (2002). Unit Root Tests in Panel Data: Asymptotic and Finite-Sample Properties. Journal of Econometrics, 108(1), 1-24. https://doi.org/10.1016/S0304-4076(01)00098-7

Merckaert, J., \& Caliari, A. (2007). Ré endettement des pays du Sud : Tirer les leçons du passé. (The Debt of The Southern Countries: Lessons from the Past). Afrique Contemporaine, 223-224(3), 61-86. https://doi.org/10.3917/afco.223.0061

Pesaran, M. H., Shin, Y., \& Smith, R. J. (2001). Bounds Testing Approaches to the Analysis of Level Relationships. Journal of Applied Econometrics, 16(3), 289-326. https://doi.org/10.1002/jae.616 
Poulain, F. (1985). La paix Carthaginoise : les conséquences économiques de Versailles in Les écrits de Keynes, Paris, Dunod, 24-46.

Raffinot, M. (2013). Mesuer le surendettement des pays à faible revenu : technique, éthique ou politique? (Measuring Debt Overhang in Low-Income Countries: Technical, Ethical or Political?) Revue Tiers Monde, (1), 51-70. https://doi.org/10.3917/rtm.213.0051

Ramasastry, A. (2007). Odious debt or odious payments? Using anti-corruption measures to prevent odious debt? The North Carolina Journal of International Law \& Commercial Regulation, XXXII(Summer), 819-839.

Roos, J. E. (2019). Why Not Default? The political Economy of Sovereign Debt. Princeton, New Jersey, Princeton University Press. https://doi.org/10.2307/j.ctv3s8skt

Sterdyniak, H. (2015). La dette publique comme produit du capitalisme financier. (Public Debt as A Product of Financial Capitalism). Regards croisés sur l'économie, 17(2), 173-186. https://doi.org/10.3917/rce.017.0173

Stiglitz, J. E., Sen, A., \& Fitoussi, J. P. (2010). Mismeasuring Our Lives Why GDP Doesn't Add Up. The New Press.

United Nations (UN). (2009). Report of the independent expert on the effects of foreign debt and other related international financial obligations of States on the full enjoyment of all human rights, particularly economic, social, and cultural rights. A/HRC/11/10, April 2009.

United Nations (UN). (2012). External Debt Sustainability and Development. Report of the Secretary-GeneralA/67/174, July.

United Nations Conference on Trade and Development (UNCTAD). (2012). Principles on Promoting Responsible Sovereign Lending and Borrowing, January 2012.

\section{Notes}

Note 1. Report submitted to the Human Rights Council in 2009 under the reference (A/HRC/11/10).

Note 2. Report submitted to the United Nations General Assembly in 2009 under the reference (A/64/289).

Note 3. The project led to the publication in 2012 of a set of "Principles on Promoting Responsible Sovereign Lending and Borrowing". These principles constitute a charter of good conduct that engages the responsibility of both lenders and sovereign borrowers.

Note 4. Including resolutions 64/191, 65/144, 66/189, 67/198, 68/202, 68/304, 69/247 and 69/319.

Note 5. Resolution A/RES/69/319 on Basic Principles on Sovereign Debt Restructuring Processes, adopted by the General Assembly on 10 September 2015 by 136 votes in favor, 41 abstentions, 10 non-voting and 6 votes against (Canada, Germany, Israel, Japan, United Kingdom and United States).

Note 6. These proposals are: (1) Putting back on the agenda the IMF's proposal on "State bankruptcy law", which was rejected in 2003; (2) Adopting the rule recommended by the 2012 treaty creating the European Stability Mechanism (ESM), which makes it mandatory to introduce collective action clauses (CACs) in euro area bond issues; (3) Including restructuring terms in the initial contract; or (4) using international financing as a lever.

Note 7. SDHA means the amount of debt service per capita. It is equal to the ratio of the annual debt service, expressed in current dollars, to the population. The values obtained must then be adjusted for purchasing power parities (PPPs) to allow a comparison of the per capita debt service, then expressed in volume terms, from one country to another at a given date.

Note 8. SDDT relates debt service to total development expenditures. It considers simultaneously and equally the problem of the substitutability of debt repayment for strictly economic development (SDIK) and human development (SDPDH). For each country, SDDT is equal to (SDIK+SDPDH)/2.

Note 9. SDPDH relates the annual amount of public debt servicing to total public expenditures on human development, i.e. health and education. SDPDH is equal to (1/[(1/SDPSA) + (1/SDPED)]).

Note 10. The indicator for the SDS indicator is therefore valid for each country.

Note 11. Terms of trade are measured by the ratio of the unit value index of exports to the unit value index of imports (reference year 2000, World Bank).

Note 12. Source for all graphs: World Bank, ratios calculated by the authors.

Note 13. For this indicator, statistics are available for Egypt between 2004 and 2008; for Lebanon between 2004 
and 2013; for Tunisia between 2004 and 2008; for Morocco in 2008 and 2009; for Turkey in 2004, 2006,2012 and 2013.

Note 14. SDI levels cannot be calculated for all years due to the lack of SDPED ratio statistics. For Morocco, only the values for the two years 2008 and 2009 are available.

Note 15 . A stationary time series is characterized by a constant mean and variance.

\section{Copyrights}

Copyright for this article is retained by the author(s), with first publication rights granted to the journal.

This is an open-access article distributed under the terms and conditions of the Creative Commons Attribution license (http://creativecommons.org/licenses/by/4.0/). 